\title{
Effects of the 2006 El Niño on tropospheric ozone and carbon monoxide: implications for dynamics and biomass burning
}

\author{
S. Chandra ${ }^{1,2}$, J. R. Ziemke ${ }^{1,2}$, B. N. Duncan ${ }^{1,2}$, T. L. Diehl ${ }^{1,2}$, N. J. Livesey ${ }^{3}$, and L. Froidevaux ${ }^{3}$ \\ ${ }^{1}$ Goddard Earth Sciences and Technology Center, University of Maryland Baltimore County, Baltimore, MD, USA \\ ${ }^{2}$ NASA Goddard Space Flight Center, Greenbelt, MD, USA \\ ${ }^{3}$ NASA Jet Propulsion Laboratory, Pasadena, CA, USA
}

Received: 24 September 2008 - Published in Atmos. Chem. Phys. Discuss.: 28 January 2009

Revised: 8 May 2009 - Accepted: 19 June 2009 - Published: 2 July 2009

\begin{abstract}
We have studied the effects of the 2006 El Niño on tropospheric $\mathrm{O}_{3}$ and $\mathrm{CO}$ at tropical and sub-tropical latitudes measured from the OMI and MLS instruments on the Aura satellite. The 2006 El Niño-induced drought caused forest fires (largely set to clear land) to burn out of control during October and November in the Indonesian region. The effects of these fires are clearly seen in the enhancement of CO concentration measured from the MLS instrument. We have used a global model of atmospheric chemistry and transport (GMI CTM) to quantify the relative importance of biomass burning and large scale transport in producing observed changes in tropospheric $\mathrm{O}_{3}$ and $\mathrm{CO}$. The model results show that during October and November biomass burning and meteorological changes contributed almost equally to the observed increase in tropospheric $\mathrm{O}_{3}$ in the Indonesian region. The biomass component was 4-6 DU but it was limited to the Indonesian region where the fires were most intense. The dynamical component was 4-8 DU but it covered a much larger area in the Indian Ocean extending from South East Asia in the north to western Australia in the south. By December 2006, the effect of biomass burning was reduced to zero and the observed changes in tropospheric $\mathrm{O}_{3}$ were mostly due to dynamical effects. The model results show an increase of 2-3\% in the global burden of tropospheric ozone. In comparison, the global burden of $\mathrm{CO}$ increased by $8-12 \%$.
\end{abstract}

\section{Introduction}

El Niño and La Niña events are major sources of inter-annual and decadal variability in tropical tropospheric ozone $\left(\mathrm{O}_{3}\right)$ (e.g., Ziemke et al., 2003). The atmospheric effects of El

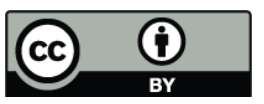

Correspondence to: J. R. Ziemke (Jerald.R.Ziemke@nasa.gov)
Niño events are generally a change in convection in the tropical troposphere associated with an eastward shift of the warm SST anomaly and large scale Walker circulation. This shift results in an increase in tropospheric column $\mathrm{O}_{3}$ in the western Pacific and a decrease in the eastern Pacific relative to non-El Niño years. The effect of El Niño on specific humidity is usually opposite to that of column ozone (e.g., Chandra et al., 1998, 2007). During La Niña years, dynamical processes are largely reversed with respect to El Niño years. The effects of El Niño on tropospheric composition have been extensively studied from both satellite and ground based measurements (e.g., Chandra et al., 1998; Fujiwara et al., 1999; Thompson et al., 2001) and by using global models of atmospheric chemistry and transport (e.g., Peters et al., 2001; Sudo and Takahashi, 2001; Chandra et al., 2002, 2003; Duncan et al., 2003; Zeng and Pyle, 2005; Doherty et al., 2006).

Recently Logan et al. (2008) studied the effects of the 2004 and 2006 El Niño events on tropospheric profiles of $\mathrm{CO}, \mathrm{O}_{3}$, and $\mathrm{H}_{2} \mathrm{O}$ measured from the Tropospheric Emission Spectrometer (TES) on the Aura satellite. Their findings were generally consistent with the observed characteristics of $\mathrm{O}_{3}$ and $\mathrm{H}_{2} \mathrm{O}$ inferred from previous El Niño events. The changes during the $2004 \mathrm{El}$ Niño in tropospheric $\mathrm{O}_{3}$ and $\mathrm{H}_{2} \mathrm{O}$ from TES are similar to those inferred from Ozone Monitoring Instrument (OMI) and Microwave Limb Spectrometer (MLS) flown on the same satellite (Chandra et al., 2007). The 2004 El Niño was a weak event compared to 2006 and significantly weaker compared to the El Niño of 1997-1998. This was reflected in the TCO (tropospheric column ozone) anomaly over the Indonesian region in the western Pacific as shown in Table 1 of Logan et al. (2008). For example, the TCO anomaly in November 1997 inferred from EP TOMS was 14.4 Dobson Units (DU; 1 DU $=2.69 \times 10^{20}$ molecules$\mathrm{m}^{-2}$ ). The corresponding values from TES for November 2004 and 2006 were 6.6 DU and 11.1 DU. Logan et al. (2008) attributed most of these changes to differences

Published by Copernicus Publications on behalf of the European Geosciences Union. 
in the magnitude of $\mathrm{CO}$ emissions from fires in Indonesia which in these years were estimated to be $193 \mathrm{Tg}, 24 \mathrm{Tg}$, and $82 \mathrm{Tg}$, respectively. They also suggested significant contribution from $\mathrm{NO}_{\mathrm{x}}$ production due to lightning in late November and December 2006 when CO production due to large scale forest fires decreased significantly. The effects of forest fires in the Indonesian region during the 1997 El Niño was studied by Chandra et al. (2002) using the GEOS-CHEM global model of chemistry and transport. Their study suggested that about half of the increase in tropospheric column ozone in the Indonesian region was due to biomass burning and the other half due to dynamical effects. A similar conclusion was arrived by Sudo and Takahashi (2001) from their model study. Their conclusion about the contribution of biomass burning was indirect since they did not explicitly include the effect of biomass burning in their model study.

The combined OMI and MLS instruments on the Aura satellite have been providing near global measurements of TCO from August 2004 to present (e.g., Ziemke et al., 2006; Schoeberl et al., 2007) as discussed in Sect. 2. In addition the MLS instrument has been providing daily measurements of $\mathrm{CO}$ at several pressure levels in the troposphere and stratosphere (Livesey et al., 2008). The purpose of this paper is to study the effects of the 2006 El Niño on tropospheric composition measured from the OMI and MLS instruments on the Aura satellite and evaluate specific roles of the various processes using a global model of chemistry and transport. The global model used in this study is the NASA GMI CTM (Global Modeling Initiative Chemical Transport Model). It successfully simulates a wide range of observations of chemical constituents in the troposphere and stratosphere, including data collected by instruments on board satellites. We provide a brief overview of the relevant tropospheric processes in the GMI CTM in Sect. 3. In our study, the El Niño related changes in $\mathrm{O}_{3}$ and $\mathrm{CO}$ fields based on OMI and MLS measurements are compared with corresponding changes based on GMI CTM simulation to delineate the relative importance of biomass burning and large scale transport.

In the following, Sect. 2 discusses the satellite data, Sect. 3 the GMI model, and Sects. 4 and 5 compare the measured $\mathrm{O}_{3}$ and $\mathrm{CO}$ with GMI model results. Section 6 discusses the impact of biomass burning emissions over Indonesia during the 2006 El Niño, and Sect. 7 compares the strength and frequency of the 2006 and recent El Niño events with previous El Niño events. Finally, Sect. 8 provides a summary.

\section{Measurements from OMI and MLS}

OMI is one out of a total of four instruments onboard the Aura spacecraft which is flown in a sun-synchronous polar orbit at $705 \mathrm{~km}$ altitude with a $98.2^{\circ}$ inclination. The spacecraft has an equatorial crossing time of 01:45 p.m. (ascending node) with around $98.8 \mathrm{~min}$ per orbit (14.6 orbits per day on average). OMI is a nadir-scanning instrument that for visible (350-500 nm) and UV wavelength channels (UV1: $270-314 \mathrm{~nm}$; UV-2: $306-380 \mathrm{~nm}$ ) detects backscattered solar radiance to measure column ozone with near global coverage (aside from polar night latitudes) over the Earth with a resolution of $13 \mathrm{~km} \times 24 \mathrm{~km}$ at nadir. Besides ozone, OMI also measures cloud-top pressure, aerosols and aerosol parameters, $\mathrm{NO}_{2}, \mathrm{SO}_{2}$, and other trace constituents in the troposphere and stratosphere (Levelt et al., 2006). Total ozone from OMI is derived from the TOMS version 8 algorithm. A description of this algorithm may be obtained from the TOMS V8 CD DVD ROM, or from the OMI Algorithm Theoretical Basis Document (ATBD) (from the webpage http://toms.gsfc.nasa.gov/version8/v8toms_atbd.pdf).

There are two standard OMI total ozone products. Here we use data from the collection 3 OMTO3 version 8.5 (v8.5) product that is based on the Total Ozone Mapping Spectrometer (TOMS) version 8 (v8) total $\mathrm{O}_{3}$ algorithm. A description of this algorithm may be obtained from the TOMS v8 DVD or the OMI Algorithm Theoretical Basis Document (ATBD) from the TOMS web page http://toms.gsfc. nasa.gov/version8/v8toms_atbd.pdf. A main difference between $\mathrm{v} 8$ and $\mathrm{v} 8.5$ is that v8.5 uses measured cloud pressure whereas v8 and earlier versions used an infrared-measured climatology for cloud pressure. Another OMI algorithm based on the Differential Optical Absorption Spectroscopy Method (DOAS) technique gives similar estimates of total column ozone (Kroon et al., 2008b). These total column $\mathrm{O}_{3}$ retrievals have been compared with ground-based data (McPeters et al., 2008) and aircraft-based measurements (Kroon et al., 2008a).

$\mathrm{O}_{3}$ profiles from the Aura Microwave Limb Sounder (MLS) are used to estimate stratospheric column $\mathrm{O}_{3}$ (SCO). The SCO is subtracted from OMI total column $\mathrm{O}_{3}$ from OMI to yield tropospheric column $\mathrm{O}_{3}$ and mean volume mixing ratio (e.g., Ziemke et al., 2006). The mean volume mixing ratio (units ppbv) is determined by taking tropospheric column $\mathrm{O}_{3}$ (in Dobson Units, DU) and dividing this by pressure difference (in units $\mathrm{hPa}$ ) between surface and tropopause, and then multiplying this by the factor 1.27. Validation of MLS v2.2 $\mathrm{O}_{3}$ and $\mathrm{CO}$ measurements are discussed by Froidevaux et al. (2008) and Livesey et al. (2008). For both v2.2 data products, the suggested lowest retrieved level for scientific use is $215 \mathrm{hPa}$. which lies below the tropopause height $(\sim 100 \mathrm{hPa})$ over most of the tropical and sub-tropical latitudes. With $\mathrm{O}_{3}$ the measurements are positively biased by $\sim 5-20 \%$ in the lower-most retrieved levels, while for $\mathrm{CO}$ there remains a bias in the lowest $215 \mathrm{hPa}$ level of about a factor of 2 . The precision for $\mathrm{O}_{3}$ varies relatively uniformly from about $0.04 \mathrm{ppmv}$ at $215 \mathrm{hPa}$ to about $0.3 \mathrm{ppmv}$ in the upper stratosphere and lower mesosphere. Precision for CO at $215 \mathrm{hPa}$ is about $40 \mathrm{ppbv}$. The vertical resolution of MLS CO and $\mathrm{O}_{3}$ over most of the stratosphere is $\sim 4 \mathrm{~km}$ and $2.5 \mathrm{~km}$, respectively, while along-track horizontal resolution is $\sim 500$ $600 \mathrm{~km}$ for $\mathrm{CO}$ and $\sim 200-300 \mathrm{~km}$ for $\mathrm{O}_{3}$. The measurements of mean tropospheric $\mathrm{O}_{3}$ from OMI/MLS and upper 
tropospheric CO from MLS are studied and compared with simulations from a global chemical transport model (discussed next).

\section{NASA Global Modeling Initiative Chemical Trans- port Model}

The GMI CTM is described and evaluated in Ziemke et al. (2006), Schoeberl et al. (2006), Strahan et al. (2007), and Duncan et al. (2007, 2008). The chemical mechanism includes 117 species, 322 chemical reactions, and 81 photolysis reactions to simulate tropospheric and stratospheric chemistry. It includes a detailed description of $\mathrm{O}_{3}-\mathrm{NO}_{\mathrm{x}}-$ hydrocarbon chemistry, updated with recent experimental data. The chemical mass balance equations are integrated using the SMVGEAR II algorithm (Jacobson, 1995). Photolysis frequencies are computed using the Fast-JX radiative transfer algorithm (M. Prather, personal communication). The algorithm treats both Rayleigh scattering as well as Mie scattering by clouds and aerosol. The CTM simulates the radiative and heterogeneous chemical effects of sulfate, dust, sea-salt, organic carbon and black carbon aerosol on tropospheric photochemistry.

Biogenic emissions of isoprene and monoterpenes are calculated on-line as described in Guenther et al. (2006). The lightning $\mathrm{NO}_{\mathrm{x}}$ parameterization fits the relationship between model-calculated convective mass fluxes and observed cloud-to-ground flash rates (D. Allen and K. Pickering, personal communication). Time-appropriate anthropogenic and biomass burning emissions include, surface emissions from industry/fossil fuel, biomass burning, biogenic and biofuel combustions and contributions from aircraft emissions. They are based on the Global Fire Emission Database, version 2 (GFEDv2) and discussed in the GMI CTM papers listed above. Monthly total biomass burning of $\mathrm{CO}$ and $\mathrm{NO}$ are shown in Table 1 for the later part of 2006 when the Indonesian fires were most intense.

Table 1 indicates that the Indonesian fires increased the CO burden by $69 \mathrm{Tg}$ during the three month period from September to November 2006. It is about $27 \%$ of the global CO burden $(251 \mathrm{Tg})$ during the same period. The increase in $\mathrm{NO}_{\mathrm{x}}$ due to Indonesian fires during the same period was $1.19 \mathrm{Tg}$ compared to the global burden of about $19.4 \mathrm{Tg}$.

The meteorological fields that drive transport are from the Goddard Modeling and Assimilation Office (GMAO) GEOS4 data assimilation system (GEOS-4-DAS) (Bloom et al., 2005). Features of the circulation, such as anticyclones, in the GMI CTM are realistically represented in the simulations because of the data constraints on meteorological analyses. The GEOS-4-DAS fields have been regridded to 42 vertical levels with a lid at $0.01 \mathrm{hPa}$. The horizontal resolution is $2.5^{\circ} \times 2^{\circ}$ (longitude by latitude). For consistency, tropospheric $\mathrm{O}_{3}$ from both the GMI model and OMI/MLS measurements are calculated using the same tropopause pressure
Table 1. Emissions of $\mathrm{CO}$ and $\mathrm{NO}$ for 2006. The units are in $\mathrm{Tg}$ $\left(1 \mathrm{Tg} \equiv 10^{12} \mathrm{~g}\right)$.

\begin{tabular}{lllll}
\hline & \multicolumn{2}{c}{ CO (Tg) } & \multicolumn{2}{c}{ NO (Tg) } \\
& Indonesia $^{\mathrm{a}}$ & World $^{\mathrm{b}}$ & Indonesia $^{\mathrm{a}}$ & World $^{\mathrm{b}}$ \\
\hline July & 5.9 & 92 & 0.10 & 7.3 \\
August & 16.6 & 103 & 0.29 & 7.4 \\
September & 18.3 & 99 & 0.32 & 6.8 \\
October & 44.2 & 73 & 0.76 & 6.3 \\
November & 6.3 & 79 & 0.11 & 6.3 \\
December & 0.2 & 103 & 0.00 & 7.1 \\
\hline
\end{tabular}

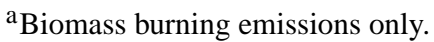

${ }^{b}$ Emissions from all sources, including fossil fuels, biofuels, and biomass burning, except biomass burning from Indonesia.

from National Centers for Environmental Protection (NCEP) analyses. The tropopause pressure is defined using the World Meteorological Organization (WMO) $2 \mathrm{~K}-\mathrm{km}^{-1}$ lapse-rate definition.

A validation of the global model used in this study is given in the Appendix. This analysis compares the zonal and seasonal variability of TCO derived from the model with observed variability from OMI/MLS. The comparisons show that the measurements and model agree well in temporal and spatial variability from the tropics out to the subtropical wind jets at around $\pm 30^{\circ}-35^{\circ}$ latitude. The comparisons also indicate that the discrepancy in seasonal variability of TOMS TCO over northern Africa as discussed by Martin et al. (2007) is reduced greatly in the OMI/MLS TCO measurements. The GMI model further suggests that the biomass burning, which occurs over northern Africa each year in spring, generates only moderate increases in $\mathrm{O}_{3}$ of $\sim 5 \mathrm{DU}$. These increases in $\mathrm{O}_{3}$ are localized about the burning region and mostly in the lower troposphere.

\section{Model comparison of El Niño related changes in $\mathrm{O}_{3}$ with satellite measurements}

As in Chandra et al. (2007) and Logan et al. (2008), we have chosen October, November and December 2005 as a baseline for estimating El Niño-related changes in these months in the preceding and the following year. Year 2005 was a neutral year from an El Niño perspective. Maps of tropospheric $\mathrm{O}_{3}$ mean mixing ratio are shown in Fig. 1a for October 2004, 2005 , and 2006. They show relative changes in ozone in the El Niño years (upper and lower panels) with respect to a non El Niño year (middle panel). All three panels show regions of minimum values near the dateline. However, both the upper and the lower panels show a greater eastward shift across the dateline which results in an increase of about $6-15 \mathrm{ppbv}$ ( $\sim-10$ DU) over the western Pacific region and a decrease of smaller magnitude east of the dateline. The increase in $\mathrm{O}_{3}$ 

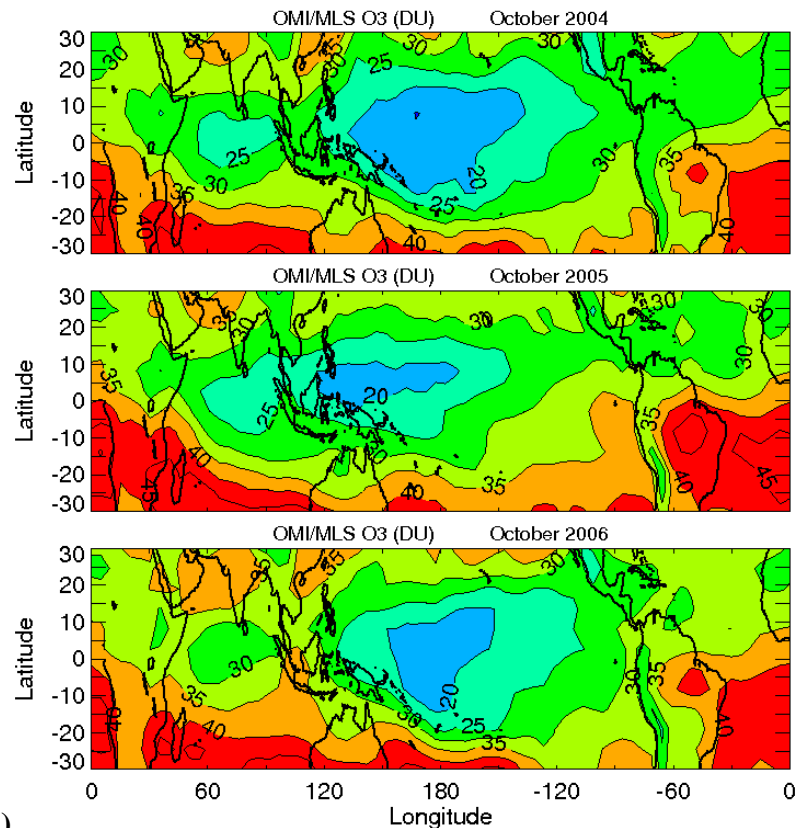

(a)
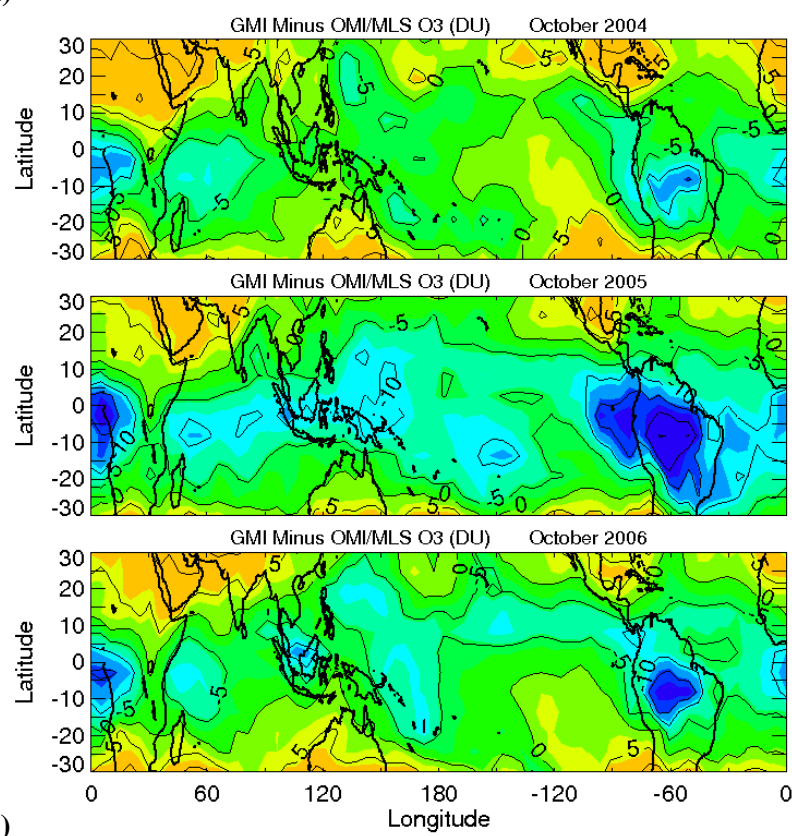
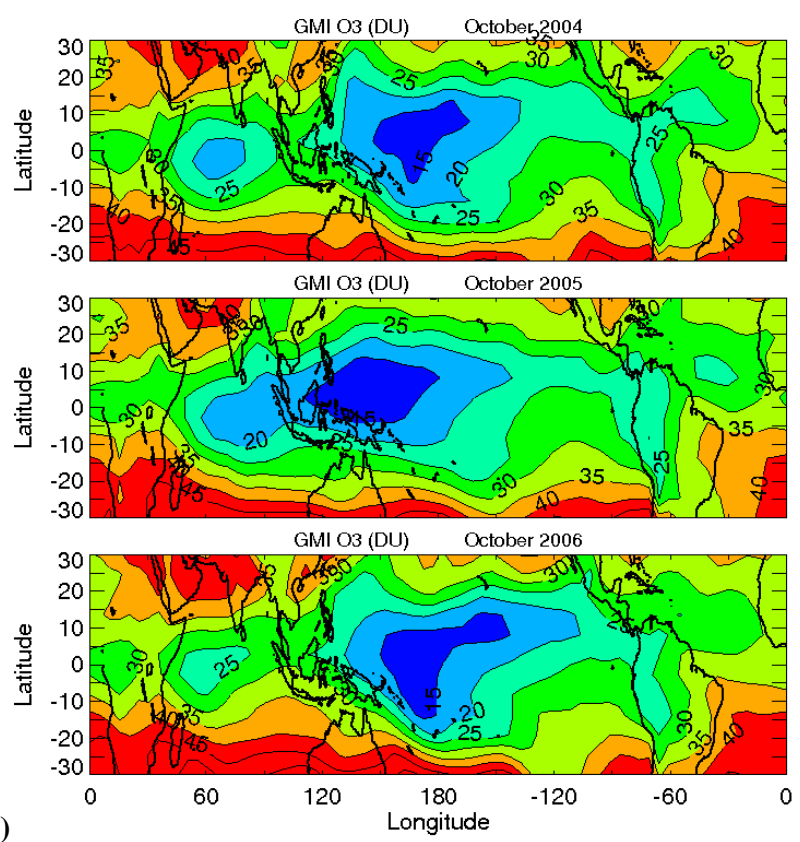

(b)

(c)

Fig. 1. (a) Tropospheric column ozone measured in DU from OMI/MLS for October 2004 (top panel), October 2005 (middle panel), and October 2006 (bottom panel). (b) Same as (a) but instead for the GMI model. (c) The difference (GMI minus OMI/MLS) between Fig. 1a and Fig. 1b.

mean mixing ratio is larger in October 2006 (lower panel) which is consistent with a relatively stronger El Niño event in 2006 compared to 2004. The model (Fig. 1b) captures most of the zonal characteristics of TCO shown in Fig. 1a, but it tends to underestimate the observed values by $5-10 \mathrm{ppbv}$ over most of the region between $\pm 10^{\circ}$. (Fig. 1c). Outside this region the sign is reversed and the model is biased higher by about the same magnitude. These pattern shifts in the model and observation are comparable in November and December months (not shown) and are similar to those shown in Fig. 2 of Ziemke et al. (2000) for the 1997 El Niño event.

The El Niño related changes in ozone in 2006 are clearly discernible in Fig. 2a, 2b and 2c. These figures show differences in OMI/MLS $\mathrm{O}_{3}$ (top panels) and the model $\mathrm{O}_{3}$ (bottom panels) between years 2006 and 2005 for the months of October-December. The model and observed values are 


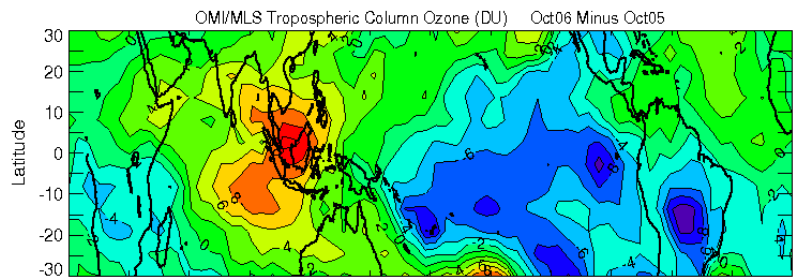

GMI Tropospheric Column Ozone (DU) Oct06 Minus Oct05

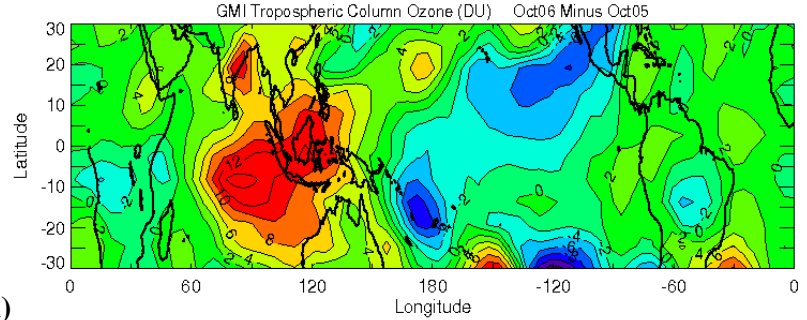

(a)
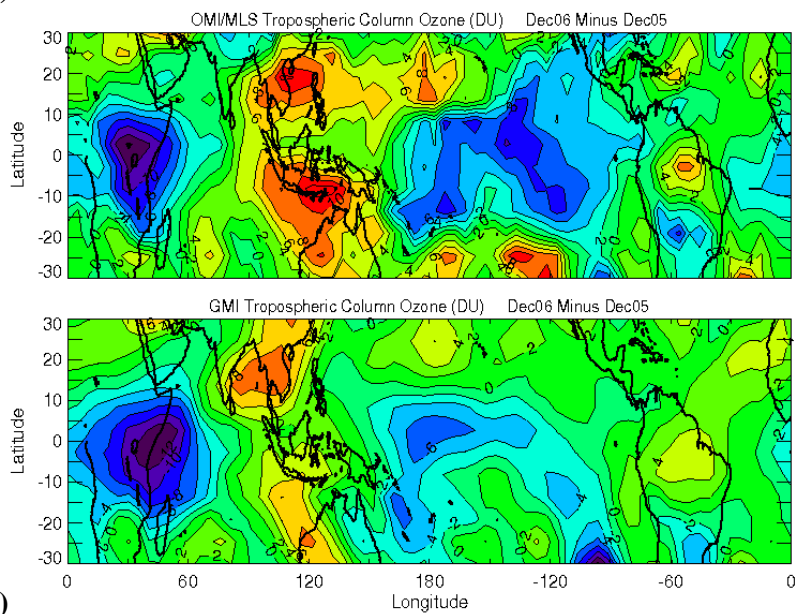
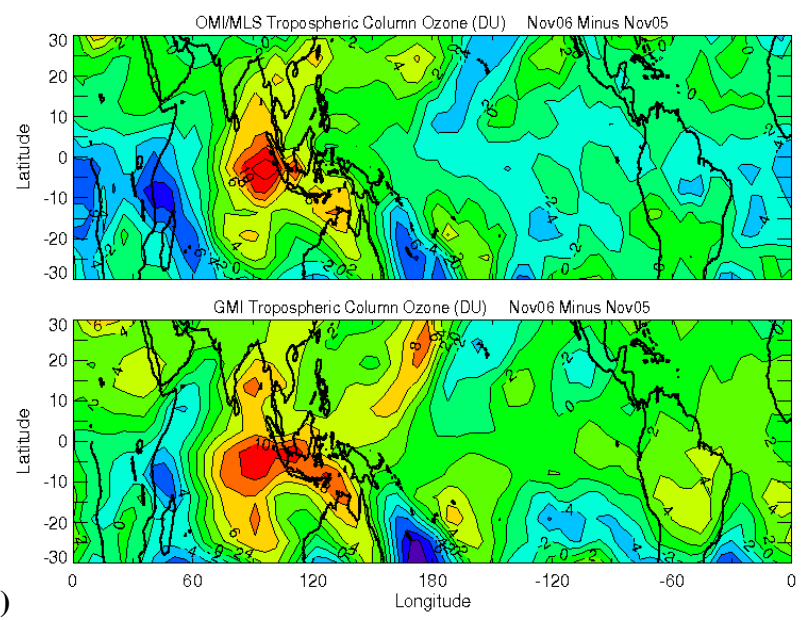

(b)

Fig. 2. (a) Inter-annual difference (October 2006 minus October 2005) of tropospheric column ozone measured in DU from OMI/MLS (top panel) and the GMI model (bottom panel). (b) Same as (a) but instead for November. (c) Same as (a) but instead for December.

generally in good agreement except in the western Pacific region in October (Fig. 2a) where the model values are biased higher. This bias is also reflected in $\mathrm{CO}$ as indicated in Sect. 5 and is probably due to overestimation of the effect of biomass burning in the Indonesian region in October 2006. In general, observations and model indicate excellent agreement in characterizing both broad and small scale features including the dipole nature of ozone anomaly in the tropical Pacific region (Fig. 2a and 2c). The large negative anomaly over eastern Africa/Indian Ocean in December 2006 seen in the data (Fig. 2c) is a manifestation of dynamically induced changes and is well produced in the model. We have analyzed the model results to estimate the contributions of the upper (above $500 \mathrm{hPa}$ ) and the lower troposphere in producing the El Niño related changes in tropospheric ozone. In general, the contributions from the upper and the lower troposphere are almost equal. However, the large negative anomaly in December in the eastern Africa/Indian Ocean (Fig. 2c) comes mostly from the upper troposphere.

\section{Model comparison of $\mathrm{CO}$ with satellite measurements}

The El Niño events of 2004 and 2006 caused droughts in the Indonesian region which allowed set fires to spread uncontrolled in both October and November of these years. The MLS measurements show a relatively larger increase in $\mathrm{CO}$ in 2006 as compared to 2004 (figure not shown). This is consistent with CO measurements from TES (Logan et al., 2008). The model results show CO to be well mixed in the free troposphere even though convection was greatly reduced in this region. During October 2006, the model shows an increase of about $200 \mathrm{ppbv}$ in the Indonesian region over much of the free troposphere. Figure $3 \mathrm{a}-\mathrm{c}$ show differences in upper tropospheric CO from MLS (top panels) and the model (bottom panels) between 2006 and 2005 for OctoberDecember. In October, both the model and measurements show elevated values of CO in 2006 over the Indonesian region in the western Pacific. One month later, in November (Fig. 3b), upper tropospheric 2006/2005 CO differences from both MLS and the model are greatly reduced. They 


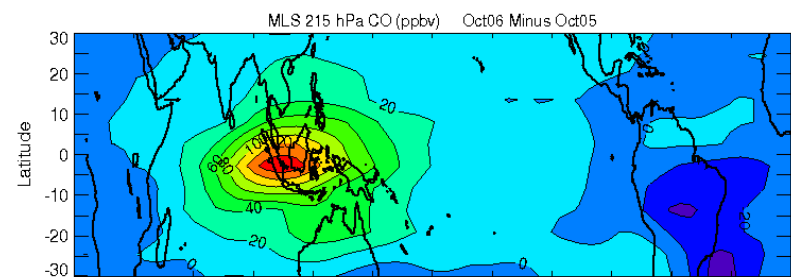

GMI $227 \mathrm{hPa} \mathrm{CO}$ (ppbv) Oct06 Minus Oct05

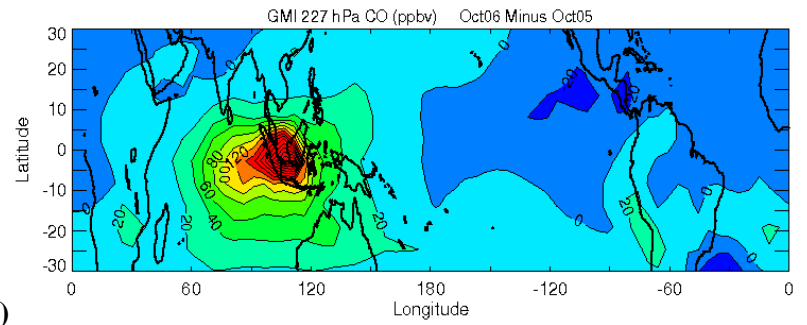

(a)

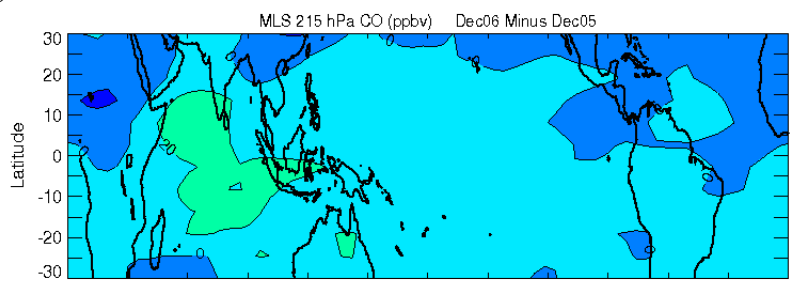

GMI $227 \mathrm{hPa} C \mathrm{Copbv}$ ) Dec06 Minus Dec05

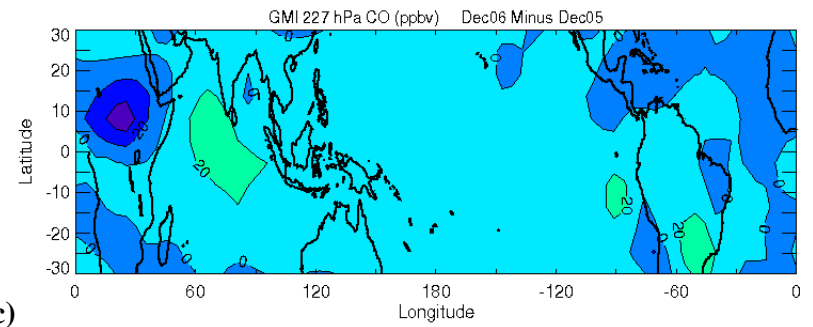

(c)
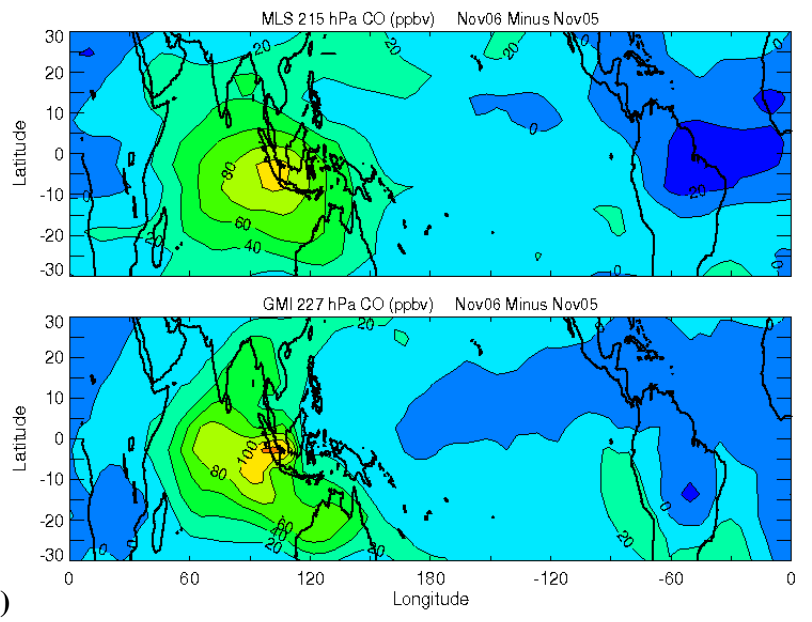

(b)

Fig. 3. (a) Inter-annual difference (October 2006 minus October 2005) of $215 \mathrm{hPa}$ CO from MLS (top panel) and $227 \mathrm{hPa}$ CO from the GMI model (bottom panel). All quantities represent volume mixing ratio in units ppbv. (b) Same as (a) but instead for November. (c) Same as (a) but instead for December.

become negligible by December as the fire subsides in this region. CO differences for both measurement and model exhibit very similar spatial and temporal patterns except in October 2006 (Fig. 3a). The model shows a sharp horizontal gradient with $\mathrm{CO}$ mixing ratio exceeding $200 \mathrm{ppbv}$ in the Indonesian region. The MLS values of CO and horizontal gradients are significantly smaller, largely due to the coarser spatial resolution of MLS limb measurements which were interpolated horizontally between orbital tracks. It is interesting to note that the large increase in $\mathrm{CO}$ in 2006 during October-November nearly disappears in December, yet $\mathrm{O}_{3}$ in December in the western Pacific remains elevated (Fig. 2c). Logan et al. (2008) attribute some of these increases in $\mathrm{O}_{3}$ due to lightning $\mathrm{NO}_{\mathrm{x}}$ in the Indonesian region.

\section{Impact of biomass burning during the 2006 EI Niño}

In Sects. 4 and 5 we analyzed the El Niño related changes in tropospheric $\mathrm{O}_{3}$ and $\mathrm{CO}$ in 2006 using both the model and observations. In this section we analyze the model results to estimate the relative importance of biomass burning and large scale transport in producing the El Niño related changes in tropospheric $\mathrm{O}_{3}$. Our approach is similar to the one used by Chandra et al. (2002) in analyzing the effect of the $1997 \mathrm{El}$ Niño on tropospheric $\mathrm{O}_{3}$. The model was run in two modes: The first mode explicitly included the $\mathrm{NO}_{\mathrm{x}}$ and $\mathrm{CO}$ emission rates associated with the Indonesian fires as given in Table 1. The results of these runs are discussed in Sects. 4 and 5. In the second mode, the model was run by excluding the contributions from the Indonesian fires. The model runs in this mode are used to assess the effects of large scale transport on tropospheric $\mathrm{O}_{3}$ as shown in the bottom panels of Fig. 4. The difference of the two runs gives the contribution from biomass burning as shown in the upper panels of Fig. 4 . 


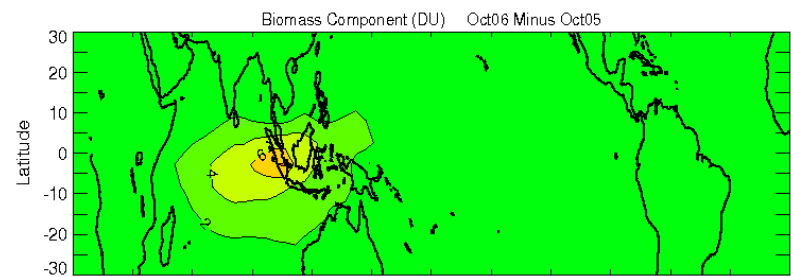

Dynamical Component (DU) Oct06 Minus Oct05

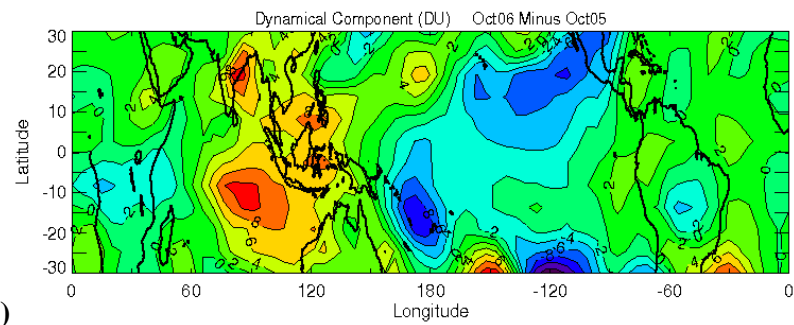

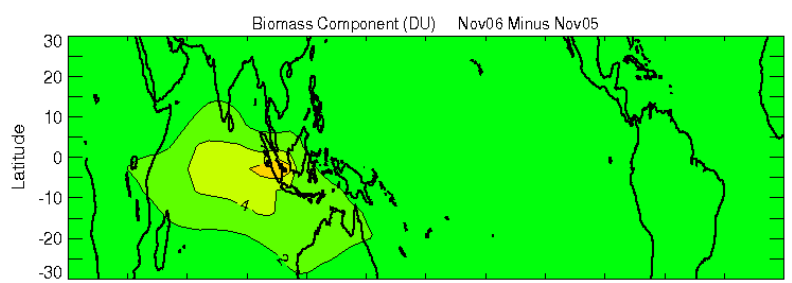

Dynarnical Component (DU) Nov06 Minus Nov05

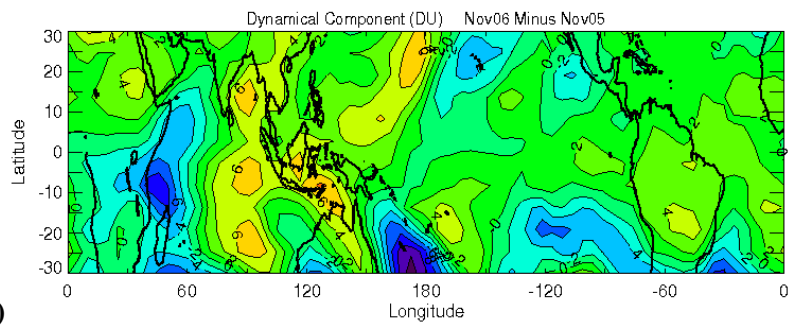

(b)

Fig. 4. (a) Inter-annual difference (October 2006 minus October 2005) of GMI tropospheric column ozone (in DU) of the Indonesia biomass burning component (top panel) and the dynamically driven component (bottom panel). (b) Same as (a) but instead for November.

In October 2006 the increase in $\mathrm{O}_{3}$ due to biomass burning is about 4-6DU (Fig. 4a, upper panel). This increase is limited to a small region comprising the islands of Sumatra, Java and Borneo in the Indonesian region. It is comparable to 4-8 DU increase caused by changes in meteorological conditions (Fig. 4a, lower panel). The latter, however, extends over a much larger area in the Indian Ocean encompassing regions of the Indian subcontinent and south-east Asia in the north, to western Australia in the south. These patterns are essentially similar in November 2006 (Fig. 4b). In December, 2006, the $\mathrm{O}_{3}$ increase due to biomass burning is reduced to zero and the dynamical component of the $\mathrm{O}_{3}$ field is identical to Fig. 2c (lower panel).

Table 2 shows the model simulations of monthly averaged global tropospheric burden of $\mathrm{CO}, \mathrm{O}_{3}$ and $\mathrm{NO}_{\mathrm{x}}$ with and without Indonesian fire emissions. The table shows that during October 2006 the Indonesian fires contributed about $36 \mathrm{Tg}$ of $\mathrm{CO}$, which was about $10.7 \%$ of the global budget. The increase in CO during November and December were respectively $12.6 \%$ and $8.1 \%$ of the global budget. These changes are significant and suggest that the El Niño related fires in the Indonesian region may have contributed significantly to global pollution. In comparison the impact of fire was relatively small $(<3 \%)$ on the global $\mathrm{O}_{3}$ burden. Logan et al. (2008) have suggested $\mathrm{NO}_{\mathrm{x}}$ production due to lightning as a contributing factor to the positive anomaly in TCO during December 2006. In our study, the $\mathrm{NO}_{\mathrm{x}}$ production due to lightning is implicitly included in the model calculations. In the tropical Pacific region $\left(12^{\circ} \mathrm{S}-12^{\circ} \mathrm{N}, 90^{\circ} \mathrm{E}-\right.$ $170^{\circ} \mathrm{E}$ ), lightning produced a total of $0.032 \mathrm{Tg} \mathrm{NO}$ in October 2006. This value increased to $0.0492 \mathrm{Tg} \mathrm{NO}$ in November and 0.0562 Tg NO in December 2006.
Table 2. Monthly averaged global tropospheric burden of $\mathrm{CO}, \mathrm{O}_{3}$, and $\mathrm{NO}_{\mathrm{x}}$ for the model. The mass units are in $\mathrm{Tg}\left(1 \mathrm{Tg} \equiv 10^{12} \mathrm{~g}\right)$.

\begin{tabular}{lllll}
\hline & Sep. & Oct. & Nov. & Dec. \\
\hline \multicolumn{5}{c}{$\mathrm{CO}(\mathrm{Tg})$} \\
Indonesia & 351 & 371 & 371 & 369 \\
No Indonesia & 336 & 335 & 329 & 341 \\
$\Delta \mathrm{CO}$ & 15 & 36 & 42 & 28 \\
$\Delta \mathrm{CO}(\%)$ & $4.6 \%$ & $10.7 \%$ & $12.6 \%$ & $8.1 \%$ \\
& \multicolumn{5}{c}{$\mathrm{O}_{3}(\mathrm{Tg})$} \\
Indonesia & 354 & 351 & 346 & 332 \\
No Indonesia & 347 & 343 & 337 & 324 \\
$\Delta \mathrm{O}_{3}$ & 8 & 8 & 10 & 8 \\
$\Delta \mathrm{O}_{3}(\%)$ & $2.2 \%$ & $2.4 \%$ & $2.8 \%$ & $2.4 \%$ \\
& \multicolumn{5}{c}{$\mathrm{NO}_{\mathrm{x}}(\mathrm{Tg} \mathrm{N})$} \\
Indonesia & 0.115 & 0.121 & 0.129 & 0.133 \\
$\mathrm{No} \mathrm{Indonesia}$ & 0.113 & 0.117 & 0.128 & 0.133 \\
$\Delta \mathrm{NO}_{\mathrm{x}}$ & 0.002 & 0.004 & 0.001 & 0.000 \\
$\Delta \mathrm{NO}_{\mathrm{x}}(\%)$ & $2.1 \%$ & $3.0 \%$ & $0.8 \%$ & $0.0 \%$ \\
\hline
\end{tabular}

\section{The El Niño of 2006: a long-term perspective}

Though the main focus of this study is the El Niño event of 2006, such events are very frequent (e.g., Ziemke et al., 2003; Fishman et al., 2005) and may have significant impact on global pollution. According to the World Meteorological Organization (WMO) an El Niño (La Niña) event is identified when sea surface temperature (SST) in the Niño 3.4 region $\left(5^{\circ} \mathrm{S}-5^{\circ} \mathrm{N}, 120^{\circ} \mathrm{W}-170^{\circ} \mathrm{W}\right)$ is at least $0.5^{\circ} \mathrm{C}$ above (below) normal when averaged over three consecutive months. The relation between $\triangle$ SST and $\triangle \mathrm{TCO}$ (the difference in TCO between eastern and western Pacific) is shown in Fig. 5. The 


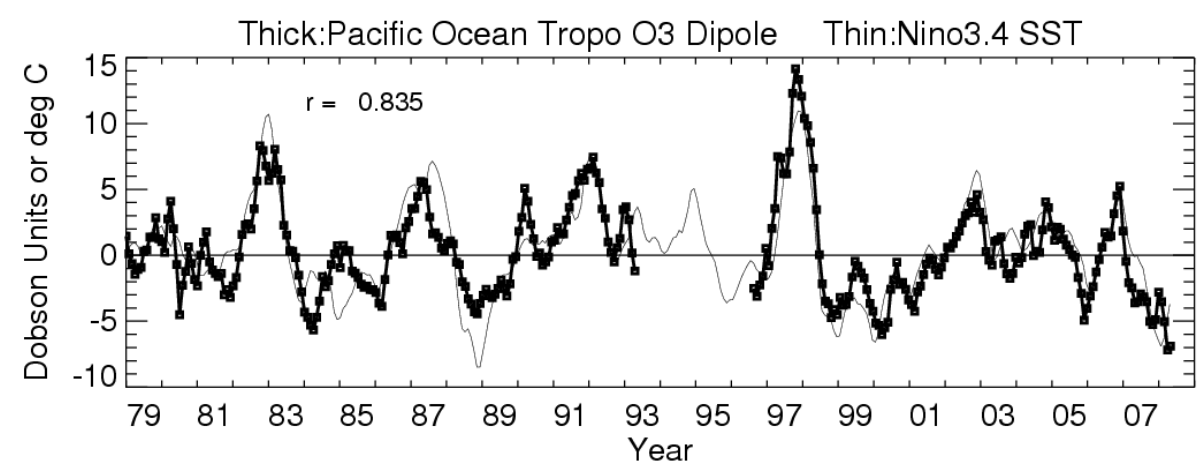

Fig. 5. OMI/MLS time series $\triangle \mathrm{TCO}$ (dark curve) plotted with Niño 3.4 time series $\Delta$ SST (light curve). $\Delta \mathrm{TCO}$ is measured in DU while $\triangle \mathrm{SST}$ is in Celsius degrees and was multiplied by a factor of three for scaling with $\triangle \mathrm{TCO}$. The $\Delta \mathrm{TCO}$ time series is derived by subtracting TCO in the eastern Pacific $\left(15^{\circ} \mathrm{S}-15^{\circ} \mathrm{N}, 135^{\circ} \mathrm{W}-180^{\circ}\right)$ from TCO in the western Pacific $\left(15^{\circ} \mathrm{S}-15^{\circ} \mathrm{N}, 95^{\circ} \mathrm{E}-140^{\circ} \mathrm{E}\right)$. The $\Delta \mathrm{TCO}$ time series was deseasonalized and was also smoothed with a three-month running average to be compatible with the Niño 3.4 time series.

$\triangle \mathrm{TCO}$ time series is derived by subtracting TCO in the eastern Pacific $\left(15^{\circ} \mathrm{S}-15^{\circ} \mathrm{N}, 135^{\circ} \mathrm{W}-180^{\circ}\right)$ from $\mathrm{TCO}$ in the western Pacific $\left(15^{\circ} \mathrm{S}-15^{\circ} \mathrm{N}, 95^{\circ} \mathrm{E}-140^{\circ} \mathrm{E}\right)$. The time series is deseasonalized and smoothed with a three-month running average to be compatible with Niño 3.4 SST. TCO is derived from 29 years (1979-2008) of total column ozone measurements from Nimbus 7 TOMS, Earth Probe TOMS and OMI using the convective cloud differential (CCD) method (e.g., Ziemke et al., 2005). Figure 5 shows a very robust correlation between $\triangle \mathrm{SST}$ and $\triangle \mathrm{TCO}$. Although the $1997 \mathrm{El}$ Niño produced largest perturbations in SST and TCO in the tropical Pacific, El Niño events like 2006 are more common. They are also episodic. Before 1997 they occurred about every 34 years, but more recently they have occurred every 2 years. A frequent occurrence of El Niño, similar to 2006, has the potential of increasing the global pollution triggered by the dryness and the resulting forest fires in the Indonesian region.

\section{Summary and conclusion}

We have studied the effects of the 2006 El Niño on tropospheric $\mathrm{O}_{3}$, and $\mathrm{CO}$ at tropical and sub-tropical latitudes measured from the OMI and MLS instruments on the Aura satellite. The zonal characteristics of observed changes in these constituents are similar to those reported by Logan et al. (2008) based on measurements of these constituents from the TES instrument on the same satellite. During October and December 2006, both these studies revealed a dipolelike structure in TCO in the tropics with an increase over the western Pacific region and a decrease over the eastern Pacific region. The dipole structure was weaker during November 2006.

The 2006 El Niño-induced drought allowed forest fires to spread rapidly during October and November in the Indonesian region. The effects of these fires are clearly seen in the enhancement of $\mathrm{CO}$ concentration, measured from both the
MLS and TES instruments. We have used a global model of atmospheric chemistry and transport (GMI CTM) to quantify the relative importance of biomass burning and large scale transport in producing observed changes in TCO. The model results show that during October and November both biomass burning and meteorological changes contributed almost equally to increases in TCO in the Indonesian region. The biomass component was 4-6 DU, limited to the Indonesian region where the fires were most intense. The dynamical component was 4-8 DU, but it covered a much larger area in the western Pacific and Indian Ocean, extending from South East Asia in the north to western Australia in the south. During December 2006 the effect of biomass burning was reduced to zero and the observed changes in TCO were mostly due to dynamical effects. Chandra et al. (2002) have obtained similar results for the $1997 \mathrm{El}$ Niño using ozone measurements from Earth Probe TOMS and comparing them with the GEOS-CHEM model. The 1997 El Niño was significantly stronger than the $2006 \mathrm{El}$ Niño and caused greater perturbations in TCO due to both forest fires and large scale transport. For the 2006 El Niño the model shows an increase of 2-3\% in the global burden of tropospheric ozone. In comparison, the global burden of CO increased by $8-12 \%$.

This study shows that the $2006 \mathrm{El}$ Niño can be characterized from long records of tropospheric $\mathrm{O}_{3}$ and sea surface temperature as a moderate event, yet the contribution to pollution from biomass burning emissions over Indonesia was substantial, both locally and also when evaluated on a global basis. In recent years El Niño events have occurred with greater frequency than in previous years dating back to 1979 . Both the frequency and scale of emissions from biomass burning suggests that even relatively moderate El Niño events can be an important source of pollution in the troposphere. 

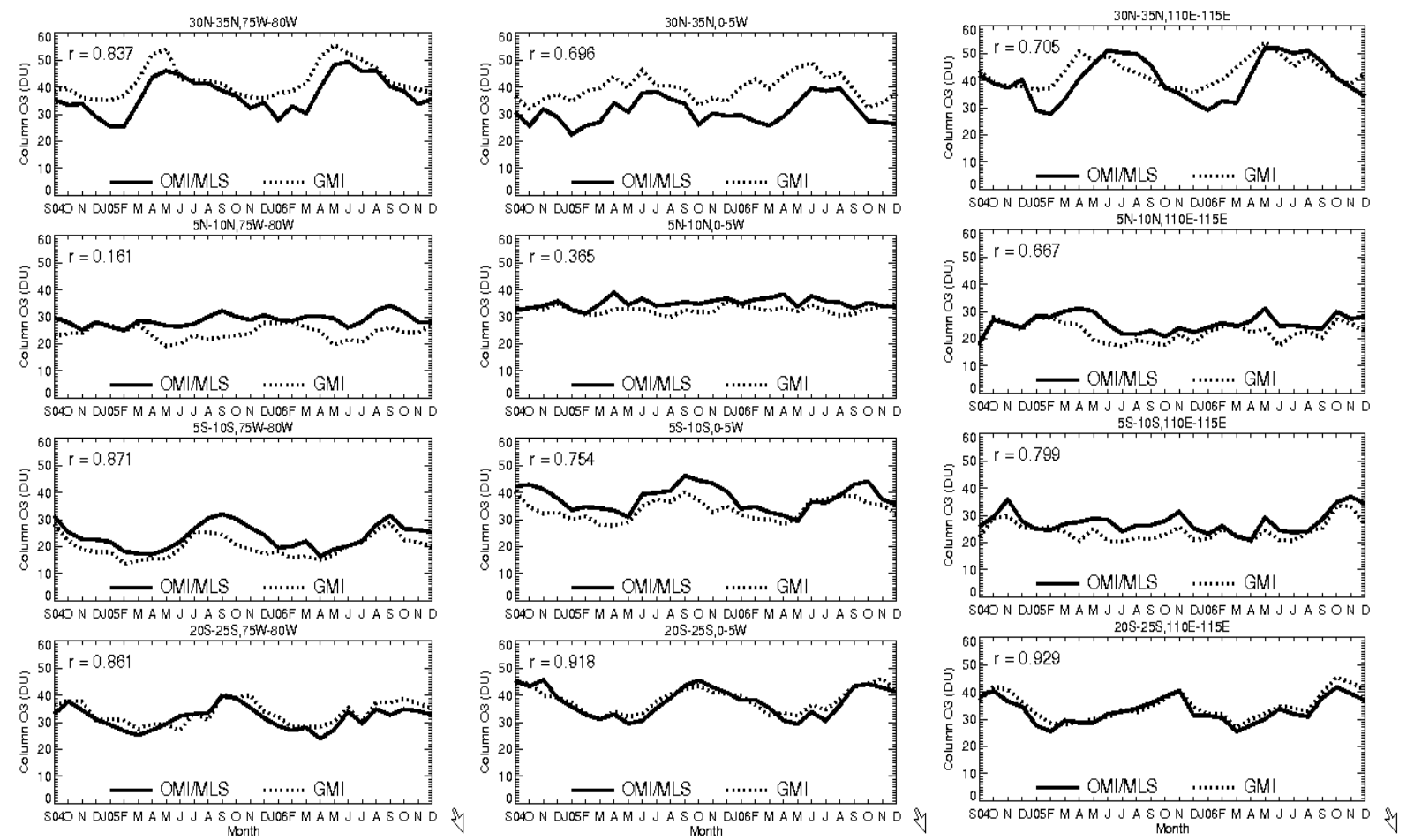

Fig. A1. Monthly time series comparisons of GMI (dotted curves) and OMI/MLS (solid curves) tropospheric column $\mathrm{O}_{3}$ (in DU) for three separate regions: American (left four panels), African (middle four panels), and Indonesian (right four panels).

\section{Appendix A}

\section{Comparisons between OMI/MLS and model $\mathrm{O}_{3}$}

Ziemke et al. (2006) compared tropospheric ozone variability derived from OMI/MLS and the GMI CTM using earlier versions of both the model and measurements. As discussed in Sect. 2, the total ozone data used in this paper is based on the TOMS version 8.5 algorithm instead of version 8 as used by Ziemke et al. (2006). The model also uses different emission sources and meteorological fields. In the following we compare the temporal/seasonal and zonal variability of TCO fields derived from the model and the measurements under varying conditions.

Figure A1 compares the temporal and seasonal variations of the model and observations for three separate regions: American (left four panels), African (middle four panels), and Indonesian (right four panels). In each region latitudes extend from north to south with the top panel being northernmost. In northern latitudes tropospheric $\mathrm{O}_{3}$ for the model and measurement maximizes around March-July. In southern latitudes largest amounts occur in September-November. In between at low latitudes the seasonal variability is small in comparison. In general the temporal variability in model and measurements are remarkably similar indicating the ability of the model to capture month-by-month variability in the data. All three top panels in Fig. A1 for the latitude band $30^{\circ} \mathrm{N}-35^{\circ} \mathrm{N}$ show offset differences of 5-10 DU (with GMI larger than OMI/MLS). For the upper right panel in Fig. A1 (corresponding to east China) the model and measured $\mathrm{O}_{3}$ in summer are comparable but the model values are larger than measured values by $5-10 \mathrm{DU}$ in winter and spring months when STE (Stratosphere Troposphere Exchange) is greatest.

Martin et al. (2002) and Chandra et al. (2002) compared the seasonal variability in tropospheric $\mathrm{O}_{3}$ from the GEOSChem model and TOMS CCD measurements. A large discrepancy was found between the model and the CCD measurements over low latitudes in northern Africa including Abidjan $\left(5^{\circ} \mathrm{N}, 4^{\circ} \mathrm{W}\right)$. The model indicated maximum tropospheric column $\mathrm{O}_{3}$ around December-February during peak time of the biomass burning whereas TOMS showed greatest amounts around June-October at a time when there is little or no biomass burning in northern Africa. Our analysis shows that the OMI and GMI model comparisons agree much better than the earlier TOMS and GEOS-Chem model comparisons regarding the seasonal variability over northern Africa. The GMI model indicates that enhancements in tropospheric $\mathrm{O}_{3}$ over northern Africa from the biomass burning lie almost entirely below $500 \mathrm{hPa}$ and are localized to relatively small regions of the burning emissions.

Figure A2 shows statistical comparisons of model and observations. The three panels in this figure show their zonal correlations (top panel), mean zonal offset difference (middle panel) and mean zonal RMS (lower panel). The grey shading 

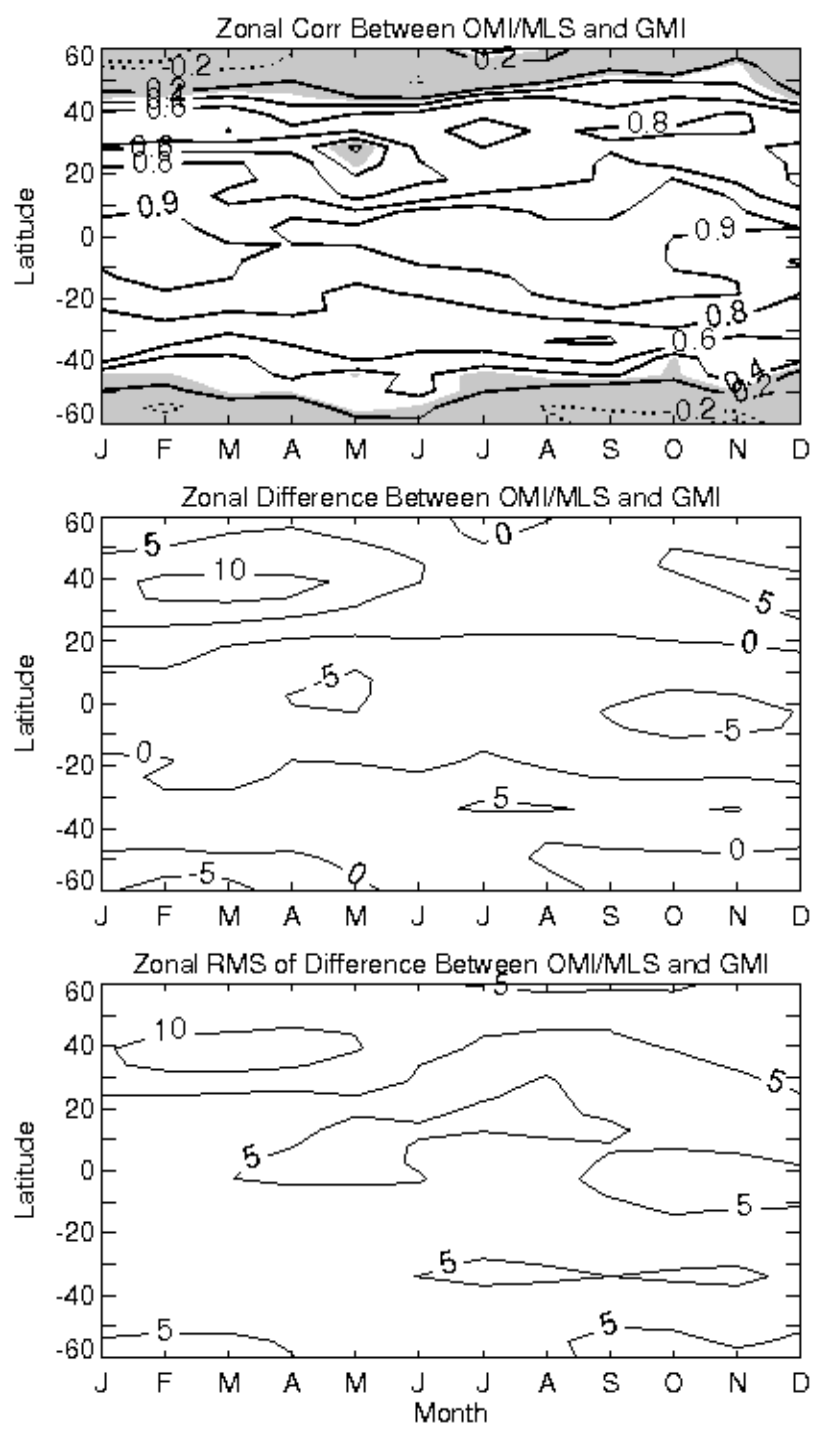

Fig. A2. (top) Zonal correlations between OMI/MLS and GMI tropospheric column $\mathrm{O}_{3}$. (middle) Calculated mean zonal offset difference (GMI minus OMI/MLS) measured in DU between model and observation. (bottom) Calculated zonal RMS of difference (GMI minus OMI/MLS) in DU. For both model and observation, fields for similar months (January-December) from 2004 to 2006 where averaged together to derive mean 12-month latitude-longitude gridded distributions of tropospheric $\mathrm{O}_{3}$. All statistical calculations were done zonally for each latitude band using the 72 gridded longitudinal values from model and observation.

in the top panel represents areas that are not statistically significant at $99.9 \%$ confidence level. Figure A2 shows that the positive correlation between the model and OMI/MLS TCO, extending out to mid-latitudes, drops to negative values in higher latitudes. Several factors could contribute to near-zero or negative cross-correlations. Aside from known model uncertainties which include STE, OMI retrievals become less sensitive in measuring tropospheric $\mathrm{O}_{3}$ in high latitudes (i.e., high solar zenith angles) and have reduced sensitivity in measuring $\mathrm{O}_{3}$ in the lower troposphere, especially for high solar zenith angles and large slant columns. The model and observations compare most favorably in the tropics and subtropics extending out to latitudes of about $\pm 30^{\circ}$ to $\pm 35^{\circ}$. This is the latitude range chosen for GMI and OMI/MLS measurements for studying the $2006 \mathrm{El}$ Niño event.

Acknowledgements. The authors thank the Aura OMI and MLS instrument and algorithm teams for the extensive satellite measurements used in this study. The OMI instrument was built by Dutch-Finnish collaboration, and is managed by the Royal Netherlands Meteorological Institute (KNMI). The authors also thank the GMI processing group for their extensive efforts in producing the GMI CTM. Data used in this study were processed at NASA Goddard Space Flight Center. Funding for this research was provided in part by Goddard Earth Science Technology (GEST) grant NGC5-494. Work at the Jet Propulsion Laboratory, California Institute of Technology, was carried out under a contract with the National Aeronautics and Space Administration.

Edited by: C. A. M. Brenninkmeijer

\section{References}

Bloom, S. C., da Silva, A. M., Dee, D. P., et al.: The Goddard Earth Observation System Data Assimilation System, GEOS DAS Version 4.0.3: Documentation and Validation, NASA TM-2005104606 V26, 2005.

Chandra, S., Ziemke, J. R., Min, W., and Read, W. G.: Effects of 1997-1998 El Niño on tropospheric ozone and water vapor, Geophys. Res. Lett., 25, 3867-3870, 1998.

Chandra, S., Ziemke, J. R., Bhartia, P. K., et al.: Tropical tropospheric ozone: Implications for dynamics and biomass burning, J. Geophys. Res., 107(D14), 4188, doi:10.1029/2001JD000447, 2002.

Chandra, S., Ziemke, J. R., and Martin, R. V.: Tropospheric ozone at tropical and middle latitudes derived from TOMS/MLS residual: Comparison with a global model, J. Geophys. Res., 108(D9), 4291, doi:10.1029/2002JD002912, 2003.

Chandra, S., Ziemke, J. R., Schoeberl, M. R., et al.: Effects of the 2004 El Niño on tropospheric ozone and water vapor, Geophys. Res. Lett., 34, L06802, doi:10.1029/2006GL028779, 2007.

Doherty, R. M., Stevenson, D. S., Johnson, C. E., et al.: Tropospheric ozone and El Niño-Southern Oscillation: Influence of atmospheric dynamics, biomass burning emissions, and future climate change, J. Geophys. Res., 111, D19304, doi:10.1029/2005JD006849, 2006.

Duncan, B. N., Martin, R. V., Staudt, A., et al.: Inter-annual and seasonal variability of biomass burning emissions constrained by satellite observations, J. Geophys. Res., 108, 4100, doi:10.1029/2002JD002378, 2003.

Duncan, B., Strahan, S. E., Yoshida, Y., Steenrod, S. D., and Livesey, N.: Model Study of the Cross-Tropopause Transport of Biomass Burning Pollution, Atmos. Chem. Phys., 7, 3713-3736, 2007, http://www.atmos-chem-phys.net/7/3713/2007/.

Duncan, B. N., West, J. J., Yoshida, Y., Fiore, A. M., and Ziemke, J. R.: The influence of European pollution on ozone in the Near 
East and northern Africa, Atmos. Chem. Phys., 8, 2267-2283, 2008,

http://www.atmos-chem-phys.net/8/2267/2008/.

Fishman, J., Creilson, J. K., Wozniak, A. E., et al.: Interannual variability of stratospheric and tropospheric ozone determined from satellite measurements, J. Geophys. Res., 110, D20306, doi:10.1029/2005JD005868, 2005.

Froidevaux, L., Jiang, Y. B., Lambert, A., et al.: Validation of Aura Microwave Limb Sounder stratospheric ozone measurements, J. Geophys. Res., 113(D15), D15S20, doi:10.1029/2007JD008771, 2008.

Fujiwara, M., Kita, K., Kawakami, S., et al.: Tropospheric ozone enhancements during the Indonesian forest fire events in 1994 and in 1997 as revealed by ground-based observations, Geophys. Res. Lett., 26, 2417-2420, 1999.

Guenther, A., Karl, T., Harley, P., et al.: Estimates of global terrestrial isoprene emissions using MEGAN (Model of Emissions of Gases and Aerosols from Nature), Atmos. Chem. Phys., 6, 31813210, 2006, http://www.atmos-chem-phys.net/6/3181/2006/.

Jacobson, M.: Computaton of global photochemistry with SMVGEAR II, Atmos. Environ., 29, 3541-2546, 1995.

Kroon, M., Petropavlovskikh, I., Shetter, R. E., Hall, S., Ullmann, K., Veefkind, J. P., McPeters, R. D., Browell, E. V., and Levelt, P.: OMI Total Ozone Column Validation with AuraAVE CAFS Observations, J. Geophys. Res., 113(D16), D15S13, doi:10.1029/2007JD008795, 2008a.

Kroon, M., Veefkind, J. P., Sneep, M., McPeters, R. D., Bhartia, P. K., and Levelt, P.: Comparing OMI-TOMS and OMI-DOAS total ozone column data, J. Geophys. Res., 113(D16), D16S28, doi:10.1029/2007JD008798, 2008b.

Levelt, P. F., Hilsenrath, E., Leppelmeier, G. W., et al.: Science objectives of the Ozone Monitoring Instrument, IEEE Geosci. Remote S., 44(5), 1199-1208, 2006.

Livesey, N. J., Filipiak, M. J., Froidevaux, L., et al.: Validation of Aura Microwave Limb Sounder O-3 and CO observations in the upper troposphere and lower stratosphere, J. Geophys. Res., 113(D15), D15S02, doi:10.1029/2007JD008805, 2008.

Logan, J. A., Megretskaia, I., Nassar, R., et al.: Effects of the 2006 El Niño on tropospheric composition as revealed by data from the Tropospheric Emission Spectrometer (TES), Geophys. Res. Lett., 35, L03816, doi:10.1020/2007GL031698, 2008.

Martin, R.V., Jacob, D. J., Logan, J. A., et al.: Interpretation of TOMS observations of tropical tropospheric ozone with a global model and in-situ observations, J. Geophys. Res., 107(D18), 4351, doi:10.1029/2001JD001480, 2002.

McPeters, R. D., Kroon, M., Labow, G. J., Brinksma, E., Balis, D., Petropavlovskikh, I., Veefkind, J. P., Bhartia, P. K., and Levelt, P.: Validation of the Aura Ozone Monitoring Instrument Total Column Ozone Product, J. Geophys. Res., 113(D15), D15S14, doi:10.1029/2007JD008802, 2008.
Peters, W., Krol, M., Dentener, F., et al.: Identification of an El Nino-Southern Oscillation signal in a multiyear global simulation of tropospheric ozone, J. Geophys. Res., 106(D10), 10398 $10402,2001$.

Schoeberl, M. R., Duncan, B. N., Douglass, A., Waters, J., Livesey, N., Read, W., and Filipiak, M.: The Carbon Monoxide Tape Recorder, Geophys. Res. Lett., 33(12), L12811, doi:10.1029/2006GL026178, 2006.

Schoeberl, M. R., Ziemke, J. R., Bojkov, B., Livesy, N., Duncan, B. N., et al.: A trajectory-based estimate of the tropospheric ozone column using the residual method, J. Geophys. Res., 112, D24S49, doi:10.1029/2007JD008773, 2007.

Strahan, S. E., Duncan, B. N., and Hoor, P.: Observationallyderived diagnostics of transport in the lowermost stratosphere and their application to the GMI chemistry transport model, Atmos. Chem. Phys., 7, 2435-2445, 2007, http://www.atmos-chem-phys.net/7/2435/2007/.

Sudo, K. and Takahashi, M.: Simulation of tropospheric ozone changes during 1997-1998 El Niño: Meteorological impact on tropospheric photochemistry, Geophys. Res. Lett., 28, 40914094, 2001.

Thompson, A. M., Witte, J. C., Hudson, R. D., et al.: Tropical tropospheric ozone and biomass burning, Science, 291, 2128-2132, 2001.

Zeng, G. and Pyle, J. A.: Influence of El Niño Southern Oscillation on stratosphere/troposphere exchange and the global tropospheric ozone budget, Geophys. Res. Lett., 32, L01814, doi:10.1029/2004GL021353, 2005.

Ziemke, J. R., Chandra, S., and Bhartia, P. K.: A new NASA data product: Tropospheric and stratospheric column ozone in the tropics derived from TOMS measurements, B. Am. Meteorol. Soc., 81, 580-583, 2000.

Ziemke, J. R. and Chandra, S.: La Nina and El Nino induced variabilities of ozone in the tropical lower atmosphere during 1970-2001, Geophys. Res. Lett., 30(3), 1142, doi:10.1029/2002GL016387, 2003.

Ziemke, J. R., Chandra, S., and Bhartia, P. K.: A 25-year data record of atmospheric ozone from TOMS Cloud Slicing: Implications for trends in stratospheric and tropospheric ozone, J. Geophys. Res., 110, D15105, doi:10.1029/2004JD005687, 2005.

Ziemke, J. R., Chandra, S., Duncan, B. N., Froidevaux, L., Bhartia, P. K., Levelt, P. F., and Waters, J. W.: Tropospheric ozone determined from Aura OMI and MLS: Evaluation of measurements and comparison with the Global Modeling Initiative's Chemical Transport Model, J. Geophys. Res., 111(D19), D19303, doi:10.1029/2006JD007089, 2006. 